\title{
Room-Temperature Solution-Processed Molybdenum Oxide as Hole Transport Layer with Ag Nanoparticles for Highly Efficient Inverted Organic Solar Cells
}

\author{
Xinchen Li, ${ }^{a}$ Wallace C. H. Choy, ${ }^{a}{ }^{a}$ Fengxian Xie, ${ }^{a}$ Shaoqing Zhang ${ }^{b}$ and Jianhui Hou ${ }^{b}$ \\ Received (in XXX, XXX) Xth XXXXXXXXX 200X, Accepted Xth XXXXXXXXX 200X \\ DOI: 10.1039/b000000x
}

While metal oxide film are typically formed by high-temperature and sputtering processes, we report an approach with the features of room-temperature, water-free and solution-based process for forming molybdenum oxide $\left(\mathrm{MoO}_{\mathrm{x}}\right)$ film of inverted organic solar cells (OSCs) by proposing vacuum treatment at 10 room temperature and selecting appropriate solvent. Remarkably, our results indicate that the vacuum treatment can introduce oxygen vacancies in the molybdenum oxide film and modify its work function for functioning as an efficient hole transport layer. To further improve OSCs performances, silver nanoparticle-molybdenum oxide $\left(\mathrm{Ag} \mathrm{NP}-\mathrm{MoO}_{\mathrm{x}}\right)$ composite film is demonstrated by the introduction of $\mathrm{Ag}$ nanoparticles in the solution. Evidences and explanations confirm that OSCs performance 15 enhancement is mainly due to the improvement of the electrical properties of $\mathrm{Ag} \mathrm{NP}-\mathrm{MoO}_{\mathrm{x}}$ composite film. With the optimized composited film, inverted OSCs with power conversion efficiency (PCE) of $7.94 \%$ are achieved. Through the demonstration of high performance inverted OSCs with different polymer materials, the water-free, room-temperature and solution-processed $\mathrm{MoO}_{\mathrm{x}}$ can contribute to the evolution of high performance OSCs such as inverted and tandem OSCs and other optoelectronic devices.

\section{1. Introduction}

In organic optoelectronic devices such as organic light emitting diodes (OLEDs) and organic solar cells (OSCs), metal oxides have been widely used as charge transport layers due to the universal energy-level alignment trends between the active layer 25 and the electrodes. ${ }^{1-8}$ For hole transport layer, one of the most promising metal oxide materials is molybdenum oxide $\left(\mathrm{MoO}_{\mathrm{x}}\right)$, which has good alignment of energy-level and more stability as compared to other commonly used hole transport materials such as acidic poly(3,4-ethylenedioythiophene):poly(styrenesulfonate) 30 (PEDOT:PSS). ${ }^{9-11}$

Besides the typical methods such as sputtering and thermally evaporation, solution processed $\mathrm{MoO}_{\mathrm{x}}$ has drawn great attention for applications in different structures of OSCs, which acts as the interfacial layer between the anode and the active layer. ${ }^{12,} 13$

${ }_{35}$ However, there are a number of challenges in processing solution $\mathrm{MoO}_{\mathrm{x}}$ film on the active layer of inverted OSCs at roomtemperature. First, instead of the commonly used water ${ }^{11,14}$ and organic solvents such as methanol, ${ }^{15}, 16$ xylene $^{17}$, we select isopropanol (IPA) as the solvent of $\mathrm{MoO}_{\mathrm{x}}$ solution, which has 40 the negligible influence on the active layer. ${ }^{18-21}$ Second, the widely used precursor methods ${ }^{15,22}$ for forming $\mathrm{MoO}_{\mathrm{x}}$ film with good hole transport properties usually require thermal annealing process. Unfortunately, many polymer materials cannot sustain such high annealing temperature, which would subsequently 45 cause inherent modifications in crystallization or molecular scission, ${ }^{23-25}$ and thus deteriorate device performances. Recently, metal oxides from low-temperature solution-process methods used as hole transport layer for inverted OSCs have been reported by others. ${ }^{21,26}$ However, the device performances of these OSCs 50 are not yet comparable to those of inverted OSCs using other efficient hole transport layers. Meanwhile, there is not clear study on metal nanoparticle-metal oxide composites by roomtemperature and solution-based process as efficient hole transport layer in organic optoelectronic devices.

55 In this work, a water-free, room-temperature and solutionprocessed approach to form $\mathrm{MoO}_{\mathrm{x}}$ film is demonstrated. The film can be used as an efficient hole transport layer of inverted OSCs. We propose to (1) introduce vacuum treatment to modify the work function of solution-processed $\mathrm{MoO}_{\mathrm{x}}$ film to form efficient ${ }_{60}$ hole transport layer without any annealing process. Meanwhile, for the practical application of the film and elimination of water induced degradation, we (2) target for water-free in forming the film. In order to favor the $\mathrm{MoO}_{\mathrm{x}}$ film formation from hydrogen molybdenum bronzes, ${ }^{27}$ we (3) dedicate to select a solvent with ${ }_{65}$ low boiling point for our solution process. Isopropanol which has low boiling point and does not degrade the underneath active polymer layer is adopted. ${ }^{21}$ The inverted OSCs using our solution-processed $\mathrm{MoO}_{\mathrm{x}}$ have comparable performances as those using thermally evaporated $\mathrm{MoO}_{3}$ film. Moreover, we can (4) 70 further improve the electrical properties of the $\mathrm{MoO}_{\mathrm{x}}$ hole transport layer by introducing silver nanoparticles (Ag NPs) for forming $\mathrm{Ag} \mathrm{NP}-\mathrm{MoO}_{\mathrm{x}}$ composite film which is difficult to be realized by conventional evaporation approaches. The analyses 
Table 1 P3HT:PCBM OSCs performances of thermally evaporated $\mathrm{MoO}_{3}$ film and solution-processed $\mathrm{MoO}_{\mathrm{x}}$ film.

\begin{tabular}{ccccc}
\hline Devices & $\mathrm{J}_{\mathrm{SC}}\left(\mathrm{mA} \mathrm{cm}^{-2}\right)$ & $\mathrm{V}_{\mathrm{OC}}(\mathrm{V})$ & $\mathrm{FF}(\%)$ & $\mathrm{PCE}(\%)$ \\
\hline Evap. $\mathrm{MoO}_{3}$ & $9.44 \pm 0.037$ & $0.63 \pm 0.007$ & $64.79 \pm 0.372$ & $3.87 \pm 0.038$ \\
Solution $\mathrm{MoO}_{\mathrm{x}}$ & $9.34 \pm 0.163$ & $0.63 \pm 0.008$ & $65.19 \pm 0.951$ & $3.84 \pm 0.065$
\end{tabular}

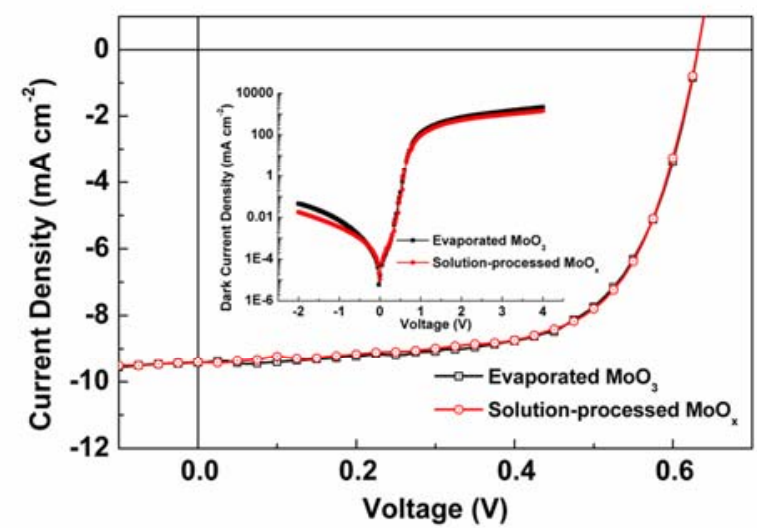

Fig. $1 \mathrm{~J}-\mathrm{V}$ characteristics of P3HT:PCBM OSCs with evaporated $\mathrm{MoO}_{3}$ 5 (black cube) and solution-processed $\mathrm{MoO}_{\mathrm{x}}$ (red circle). (Inset: Dark current density-Voltage $\left(\mathrm{J}_{\mathrm{dark}}-\mathrm{V}\right)$ characteristics of OSCs with thermally evaporated $\mathrm{MoO}_{3}$ (black cube) and solution-processed $\mathrm{MoO}_{x}$ (red circle).)

show that the proposed vacuum approach can create oxygen vacancies in the film and thus modify the work function of $\mathrm{MoO}_{\mathrm{x}}$

10 film for favoring its hole transport properties in OSCs. By further introducing the $\mathrm{Ag} \mathrm{NP}-\mathrm{MoO}_{\mathrm{x}}$ composite interfacial layer in the inverted structure OSCs, average power conversion efficiency (PCE) of $7.94 \%$ is achieved. Consequently, through the demonstration of high performance inverted OSCs with different

15 polymer materials, the water-free, room-temperature and solution-processed $\mathrm{MoO}_{\mathrm{x}}$ efficient hole transport layer can contribute to the evolution of high performance OSCs such as inverted and tandem OSCs and other optoelectronic devices.

\section{Results and Discussion}

20 To form molybdenum oxide film from proper solution approach, we oxidize molybdenum powder by using hydrogen peroxide in ethanol. Importantly, ethanol is used to control the oxidation rate of molybdenum by hydrogen peroxide to obtain hydrogen molybdenum bronze solution as described in experimental 25 section. The synthesized hydrogen molybdenum bronze solution is dried and dissolved into IPA without any water. After spincoating the solution directly onto the active layer of OSC, the sample is treated at room temperature in $10 \mathrm{~Pa}$ vacuum chamber for 10 min. Finally inverted OSCs are completed with thermal 30 deposit silver anode. More details of the synthesis and film formation can be found in experimental section. The optimized thickness of $\mathrm{MoO}_{\mathrm{x}}$ film of inverted OSCs is $8 \mathrm{~nm}$ through the devices performances, which can be found in ESI Fig. S1.

Inverted structure OSCs with its intrinsic stability and easy 35 fabrication method, are commonly formed by using thermally evaporated $\mathrm{MoO}_{3}$ as hole transport layer. ${ }^{28,29}$ Compared with the control devices with thermally evaporated $\mathrm{MoO}_{3}$, the solar cells with the solution-processed $\mathrm{MoO}_{\mathrm{x}}$ thin film have similar device

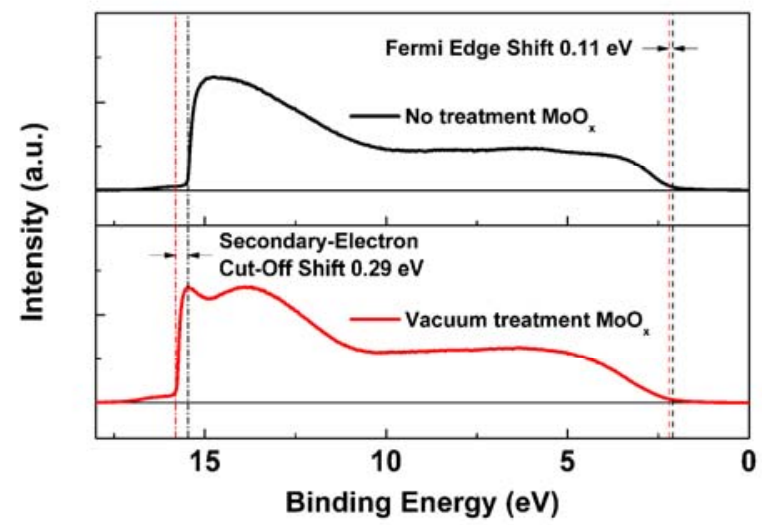

40 Fig. 2 UPS spectra of no vacuum treatment $\mathrm{MoO}_{\mathrm{x}}$ film and vacuum treatment $\mathrm{MoO}_{\mathrm{x}}$ film. The shifts of Fermi edge and secondary-electron cut-off are $0.11 \mathrm{eV}$ and $0.29 \mathrm{eV}$, respectively.

performances, while our approach have the features of water-free, room-temperature, and solution based process. As shown in Table 451 and Fig. 1, the PCE of the optimized solution-processed $\mathrm{MoO}_{\mathrm{x}}$ inverted OSCs using robust poly(3-hexylthiophene):[6,6]-phenyl C61-butyric acid methyl ester (P3HT:PCBM) active layer is $3.84 \%$ with the comparison to $3.87 \%$ of the control devices. The structure of inverted OSCs is ITO/TiO $/ 23 \mathrm{HT}: \mathrm{PCBM} / \mathrm{MoO}_{\mathrm{x}} / \mathrm{Ag}$. 50 Their short-circuit current density $\left(\mathrm{J}_{\mathrm{SC}}\right)$ are $9.34 \mathrm{~mA} \mathrm{~cm}$ (solution-processed $\mathrm{MoO}_{\mathrm{x}}$ ) and $9.44 \mathrm{~mA} \mathrm{~cm}^{-2}$ (evaporated $\mathrm{MoO}_{3}$ ). The fill factors (FF) are $65.19 \%$ (solution) and $64.79 \%$ (evaporated), with the same open-circuit voltage $\left(\mathrm{V}_{\mathrm{OC}}\right) 0.63 \mathrm{~V}$. By incorporating Ag NPs to form the Ag NP-MoO $\mathrm{M}_{\mathrm{x}}$ composite ${ }_{55}$ film, the device performances of the inverted OSCs can be further enhanced and perform better than control devices, as will be described later.

\subsection{Contributions of the vacuum treatment}

The challenges to make the solution-based process $\mathrm{MoO}_{\mathrm{x}}$ at room 60 temperature functioning as highly efficient hole transport layer for inverted OSCs lie at (1) forming the $\mathrm{MoO}_{\mathrm{x}}$ layer without any thermal annealing, (2) achieving good hole transport properties, and (3) realizing suitable work function. Here, with the strategic selection of IPA (i.e. low boiling point and not degrading the ${ }_{65}$ underneath active layer), we propose to use vacuum treatment.

To investigate the reason of the room-temperature solutionprocessed $\mathrm{MoO}_{\mathrm{x}}$ film working as an efficient hole transport layer on the active layer of inverted OSCs, the properties of $\mathrm{MoO}_{\mathrm{x}}$ thin film formed before and after the vacuum treatment have been 70 studied. The energy band structure of the $\mathrm{MoO}_{\mathrm{x}}$ film is investigated by ultraviolet photoelectron spectroscopy (UPS) measurement. The UPS spectra of the $\mathrm{MoO}_{\mathrm{x}}$ film after 10 minutes of vacuum treatment at $10 \mathrm{~Pa}$ and control $\mathrm{MoO}_{\mathrm{x}}$ film without the vacuum treatment are shown in Fig. 2. The results 75 illustrates that $\mathrm{MoO}_{\mathrm{x}}$ thin film with the vacuum treatment has clear shift at Fermi edge and secondary-electron cut-off as compared with the control film, depending on Fermi Level $\left(\mathrm{E}_{\mathrm{F}}\right)$ shift of $\mathrm{MoO}_{\mathrm{x}}$ thin film. ${ }^{15}$ The energy difference between conduction band $(\mathrm{CB})$ and valance band $(\mathrm{VB})$, i.e. the optical 80 band gap $\left(\mathrm{E}_{\mathrm{opt}}\right)$, can be determined from the extrapolated line of the linear part of photon energy curve in the plot of $(\alpha \mathrm{h} v)^{1 / 2}$ and $\mathrm{h} v$ (see ESI Fig. S2). $\mathrm{E}_{\mathrm{opt}}$ is the intersection of the extrapolated 


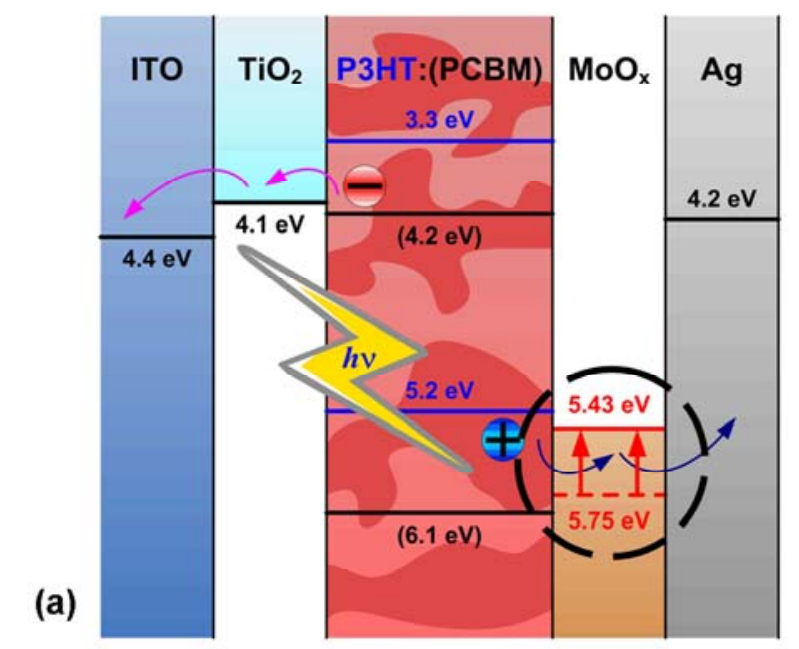

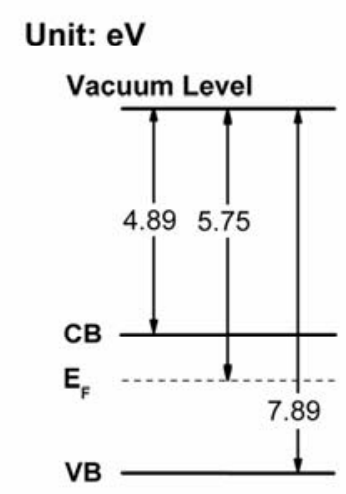

(b)

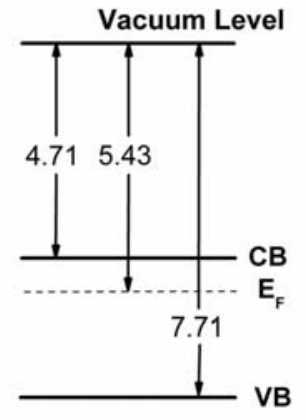

Vacuum treatment $\mathrm{MoO}_{\mathrm{x}}$

Fig. 3 (a) Schematic band diagram of inverted OCSs with the structure of ITO/TiO $2 /$ P3HT:PCBM/MoO $/ \mathrm{Ag}$. (b) Energy-level diagrams in details of no treatment $\mathrm{MoO}_{\mathrm{x}}(\mathrm{left})$ and vacuum treatment $\mathrm{MoO}_{\mathrm{x}}$ (right).

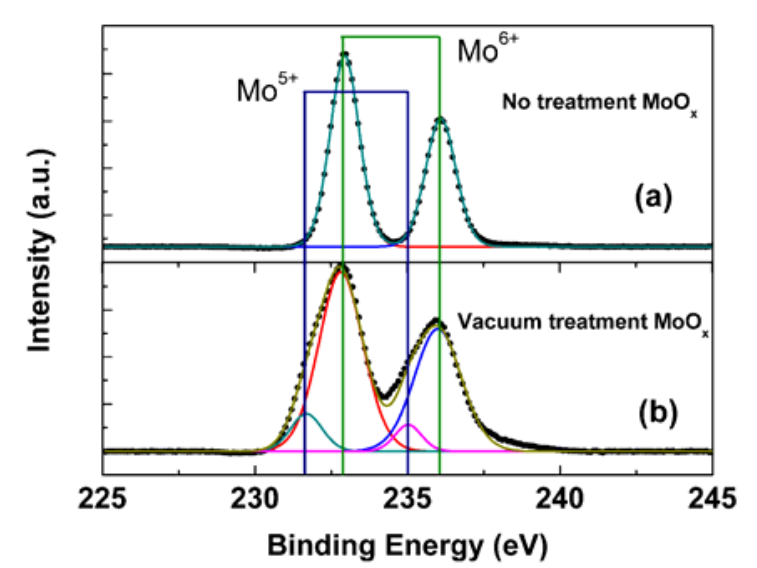

Fig. 4 XPS results of (a) $\mathrm{MoO}_{\mathrm{x}}$ layer with no treatment and (b) $\mathrm{MoO}_{\mathrm{x}}$ layer with vacuum treatment. The black dot lines are experimental XPS results. The solid lines are decomposed XPS data results.

line and the energy axis (hv). The energy-level of CB and VB can 10 be calculated following the description in elsewhere. ${ }^{30}$ So the schematic band diagram of the bulk heterojunction OSCs using blend P3HT:PCBM is shown in Fig. 3a. Details of the energylevel shift of the $\mathrm{MoO}_{\mathrm{x}}$ films with and without vacuum treatment can be found in Fig. 3b. From the analysis, it indicates that the 15 work function of the $\mathrm{MoO}_{\mathrm{x}}$ film can be significantly modified from the original $5.75 \mathrm{eV}$ to $5.43 \mathrm{eV}$ by vacuum treatment, which is more suitable for applying as hole transport layer of OSCs.

In order to determine the origin of the work function change of $\mathrm{MoO}_{\mathrm{x}}$ film due to the vacuum treatment, high-resolution X-ray 20 photoelectron spectroscopy (XPS) measurement is used to study the chemical characteristics and stoichiometry of the $\mathrm{MoO}_{\mathrm{x}}$ films with and without vacuum treatment. Compared with the untreated $\mathrm{MoO}_{\mathrm{x}}$ film, Fig. 4 shows the vacuum treated film has different XPS peaks. According to the standard peak value of carbon ${ }_{25} 284.6 \pm 0.1 \mathrm{eV}$, Mo peaks can indicate the stoichiometric composition of the $\mathrm{MoO}_{\mathrm{x}}$ film. As shown in Fig. 4, the untreated
$\mathrm{MoO}_{\mathrm{x}}$ film is mainly featured in two $3 \mathrm{~d}$ doublet Gaussian peaks. They are centered at $232.9 \mathrm{eV}$ and $236.1 \mathrm{eV}$ and close to the $3 \mathrm{~d} 5 / 2$ and $3 \mathrm{~d} 3 / 2 \mathrm{Mo}^{6+}$ oxidization states with values of $232.8 \mathrm{eV}$ 30 and $235.9 \mathrm{eV}$ respectively. ${ }^{31-33}$ Interestingly, the vacuum treated $\mathrm{MoO}_{\mathrm{x}}$ film not only shows major Gaussian peaks at $232.8 \mathrm{eV}$ and $236 \mathrm{eV}$, but also shows clear minor Gaussian peaks at $231.7 \mathrm{eV}$ and $235 \mathrm{eV}$. The major and minor peaks separately reveal $3 \mathrm{~d}$ doublet of $\mathrm{Mo}^{6+}$ and $\mathrm{Mo}^{5+}$ oxidation states. In addition, the atomic 35 concentration ratio of the two states is nearly 5:1. These results indicate that the vacuum treatment offers oxygen vacancies into the molybdenum oxide film. ${ }^{34,35}$ The introduction of vacancies in $\mathrm{MoO}_{\mathrm{x}}$ film can form complex aggregate centers, which will modify the Fermi level and enhance the charge transfer in the thin 40 film, ${ }^{36,37}$ as confirmed by the band structure and work function determined by UPS. Consequently, it is remarkable to note that the vacuum treatment can functionalize the $\mathrm{MoO}_{\mathrm{x}}$ film into an efficient hole transport layer of OSCs.

The performances of inverted OSCs using the solution${ }_{45}$ processed $\mathrm{MoO}_{\mathrm{x}}$ thin film as hole transport layer have been investigated with device structure of ITO/ $/ \mathrm{TiO}_{2} / \mathrm{P} 3 \mathrm{HT}: \mathrm{PCBM} /$ $\mathrm{MoO}_{\mathrm{x}} / \mathrm{Ag}$. As compared to the optimized control inverted OSCs using thermally evaporated molybdenum oxide, the optimized solution processed $\mathrm{MoO}_{\mathrm{x}}$ device shows similar performance. In ${ }_{50}$ fact, the inverted OSC with solution-processed $\mathrm{MoO}_{\mathrm{x}}$ has better diode characteristics and less leakage current under reverse bias voltage (see the inset of Fig. 1). The incident photon-to-current conversion efficiency (IPCE) spectra of the inverted OSCs with thermally evaporated molybdenum oxide and solution processed ${ }_{55} \mathrm{MoO}_{\mathrm{x}}$ are also similar as shown in ESI Fig. S3. Beside the polymer blend of P3HT:PCBM, the inverted OSCs made from high performance low band gap material of poly\{[4,8-bis-(2ethyl-hexyl-thiophene-5-yl)-benzo[1,2-b:4,5-b'] dithiophene-2,6diyl]-alt-[2-(2'-ethyl-hexanoyl)-thieno[3,4-b]thiophen-4,6-diyl]\}

60 (PBDTTT-C-T) $)^{38,39}$ blended with [6,6]-phenyl $\mathrm{C}_{71}$-butyric acid methyl ester $\left(\mathrm{PC}_{71} \mathrm{BM}\right)$ are also investigated. The $\mathrm{J}-\mathrm{V}$ and dark current density $\left(\mathrm{J}_{\text {dark }}\right)-\mathrm{V}$ characteristics show similar characteristics as compared with the low band gap inverted OSCs 

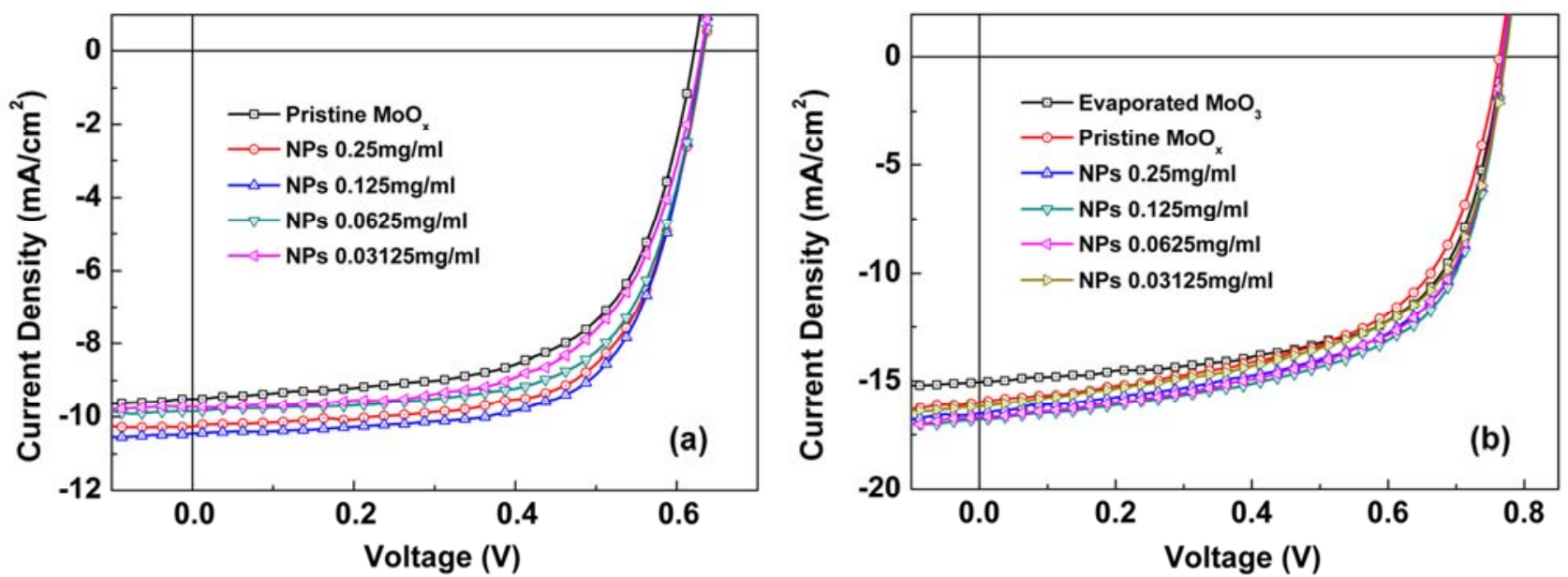

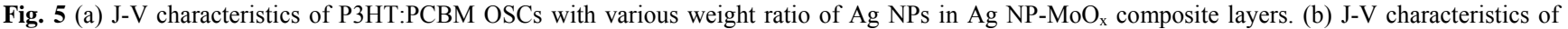

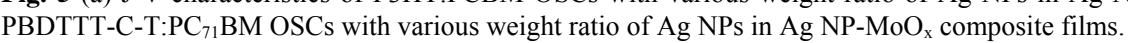

5 Table 2 P3HT:PCBM OSCs with different weight ratios of Ag NPs in the Ag NP-MoO ${ }_{x}$ composite film.

\begin{tabular}{ccccc}
\hline $\begin{array}{c}\mathrm{NPs} \\
\text { concentration }\end{array}$ & $\mathrm{J}_{\mathrm{SC}}\left(\mathrm{mA} \mathrm{cm}^{-2}\right)$ & $\mathrm{V}_{\mathrm{OC}}(\mathrm{V})$ & $\mathrm{FF}(\%)$ & $\mathrm{PCE}(\%)$ \\
\hline Pristine $\mathrm{MoO}_{\mathrm{x}}$ & $9.34 \pm 0.163$ & $0.63 \pm 0.008$ & $65.19 \pm 0.951$ & $3.84 \pm 0.065$ \\
$0.25 \mathrm{mg} / \mathrm{ml}$ & $10.25 \pm 0.135$ & $0.63 \pm 0.007$ & $65.56 \pm 0.450$ & $4.25 \pm 0.045$ \\
$0.125 \mathrm{mg} / \mathrm{ml}$ & $10.36 \pm 0.101$ & $0.63 \pm 0.007$ & $66.89 \pm 0.984$ & $4.37 \pm 0.056$ \\
$0.0625 \mathrm{mg} / \mathrm{ml}$ & $9.83 \pm 0.196$ & $0.63 \pm 0.006$ & $65.27 \pm 0.555$ & $4.07 \pm 0.097$ \\
$0.03125 \mathrm{mg} / \mathrm{ml}$ & $9.65 \pm 0.083$ & $0.63 \pm 0.007$ & $65.35 \pm 0.151$ & $3.97 \pm 0.064$ \\
\hline
\end{tabular}

Table 3 PBDTTT-C-T:PC ${ }_{71}$ BM OSCs with different weight ratios of Ag $\mathrm{NPs}$ in the Ag NP-MoO ${ }_{x}$ composite film.

\begin{tabular}{ccccc}
\hline $\begin{array}{c}\text { NPs } \\
\text { concentration }\end{array}$ & $\mathrm{J}_{\mathrm{SC}}\left(\mathrm{mA} \mathrm{cm}^{-2}\right)$ & $\mathrm{V}_{\mathrm{OC}}(\mathrm{V})$ & $\mathrm{FF}(\%)$ & $\mathrm{PCE}(\%)$ \\
\hline Evap. MoO3 & $15.01 \pm 0.409$ & $0.77 \pm 0.006$ & $63.62 \pm 0.249$ & $7.31 \pm 0.243$ \\
Pristine MoOx & $15.98 \pm 0.155$ & $0.77 \pm 0.007$ & $58.37 \pm 0.373$ & $7.15 \pm 0.148$ \\
$0.25 \mathrm{mg} / \mathrm{ml}$ & $16.51 \pm 0.261$ & $0.77 \pm 0.007$ & $60.73 \pm 0.673$ & $7.69 \pm 0.107$ \\
$0.125 \mathrm{mg} / \mathrm{ml}$ & $16.75 \pm 0.146$ & $0.77 \pm 0.007$ & $61.57 \pm 0.712$ & $7.94 \pm 0.062$ \\
$0.0625 \mathrm{mg} / \mathrm{ml}$ & $16.54 \pm 0.290$ & $0.77 \pm 0.006$ & $60.62 \pm 0.722$ & $7.65 \pm 0.133$ \\
$0.03125 \mathrm{mg} / \mathrm{ml}$ & $16.08 \pm 0.171$ & $0.77 \pm 0.005$ & $59.74 \pm 0.781$ & $7.41 \pm 0.079$
\end{tabular}

10

using thermally evaporated molybdenum oxide. With our solution-processed $\mathrm{MoO}_{\mathrm{x}}$ film, the PCE of OSCs using low band gap material can reach $7.15 \%$. Consequently, through the vacuum treatment, the water-free, room-temperature and solution-process

$15 \mathrm{MoO}_{\mathrm{x}}$ layer can function as an efficient hole transport layer in various inverted OSCs made from different polymer blends including robust P3HT:PCBM and low band gap polymer blend of PBDTTT-C-T:PC ${ }_{71} \mathrm{BM}$. The results illustrate that our vacuum approach highly efficient hole transport $\mathrm{MoOx}$ film can be
20 suitable for a variety of donor materials in OSCs with its universal energy-level alignment ability.

\subsection{Ag NP-MoO $\mathrm{M}_{\mathrm{x}}$ composite film for high performance inverted OSCs}

To achieve further performance improvement of our room25 temperature solution-processed $\mathrm{MoO}_{\mathrm{x}}$, we introduce $\mathrm{Ag}$ NPs into the solution to form $\mathrm{Ag} \mathrm{NP}-\mathrm{MoO}_{\mathrm{x}}$ composite film. Since the optimized solution-processed $\mathrm{MoO}_{\mathrm{x}}$ thin film is about $8 \mathrm{~nm}$, we would like to have the Ag NPs with size $(4 \mathrm{~nm})$ smaller than the thickness of the $\mathrm{MoO}_{\mathrm{x}}$ film. The device performances of ${ }_{30}$ P3HT:PCBM and PBDTTT-C-T:PC ${ }_{71} \mathrm{BM}$ inverted OSCs with different concentrations of Ag NPs are shown in Table 2 and Table 3, and their $\mathrm{J}-\mathrm{V}$ characteristics are shown in Fig. 5a (P3HT:PCBM) and Fig. 5b (PBDTTT-C-T:PC $\left.{ }_{71} B M\right)$. The $\mathrm{J}_{\text {dark }}-\mathrm{V}$ characteristics are shown in ESI Fig. S4 (P3HT:PCBM) and Fig. ${ }_{35} \mathrm{~S} 5$ (PBDTTT-C-T:PC ${ }_{71} \mathrm{BM}$ ) respectively. The optimized concentration of Ag NPs in the composites solution is $0.125 \mathrm{mg}$ $\mathrm{ml}^{-1}$ for both P3HT:PCBM and PBDTTT-C-T:PC ${ }_{71} \mathrm{BM}$ inverted OSCs. The results show that $\mathrm{J}_{\mathrm{SC}}$ and $\mathrm{FF}$ are significantly increased while $\mathrm{V}_{\mathrm{OC}}$ remains almost unchanged. As a result, by

40 introducing the Ag NPs with the optimized concentration into the solution-processed $\mathrm{MoO}_{\mathrm{x}}, \mathrm{PCE}$ of P3HT:PCBM based OSCs and PBDTTT-C-T:PC ${ }_{71} \mathrm{BM}$ based OSCs can be increased from $3.84 \%$ (no $\mathrm{Ag} \mathrm{NPs}$ ) to $4.37 \%$ and from $7.15 \%$ (no Ag NPs) to $7.94 \%$, respectively.

45 By using the polymer blend of P3HT:PCBM, we investigate the reasons of the performance enhancement. With the incorporation of $\mathrm{Ag}$ NPs, the optical properties of the $\mathrm{MoO}_{\mathrm{x}}$ film and OSCs are firstly studied. Recently, plasmonic resonances due to metal NPs have been widely investigated for enhancing the 50 optical absorption of OSCs. ${ }^{40-43}$ Fig. $6 \mathrm{a}$ and Fig. $6 \mathrm{~b}$ successively reveal the transmission spectra of $\mathrm{MoO}_{\mathrm{x}}$ film and the absorption spectra of the active layer with a top layer of $\mathrm{MoO}_{\mathrm{x}}$ film. The average diameter of the Ag NPs is $4 \mathrm{~nm}$, which is measured by Transmission electron microscope (TEM) and captured in the ${ }_{55}$ inset of Fig. 6b. Nevertheless, the incorporation of Ag NPs in the 

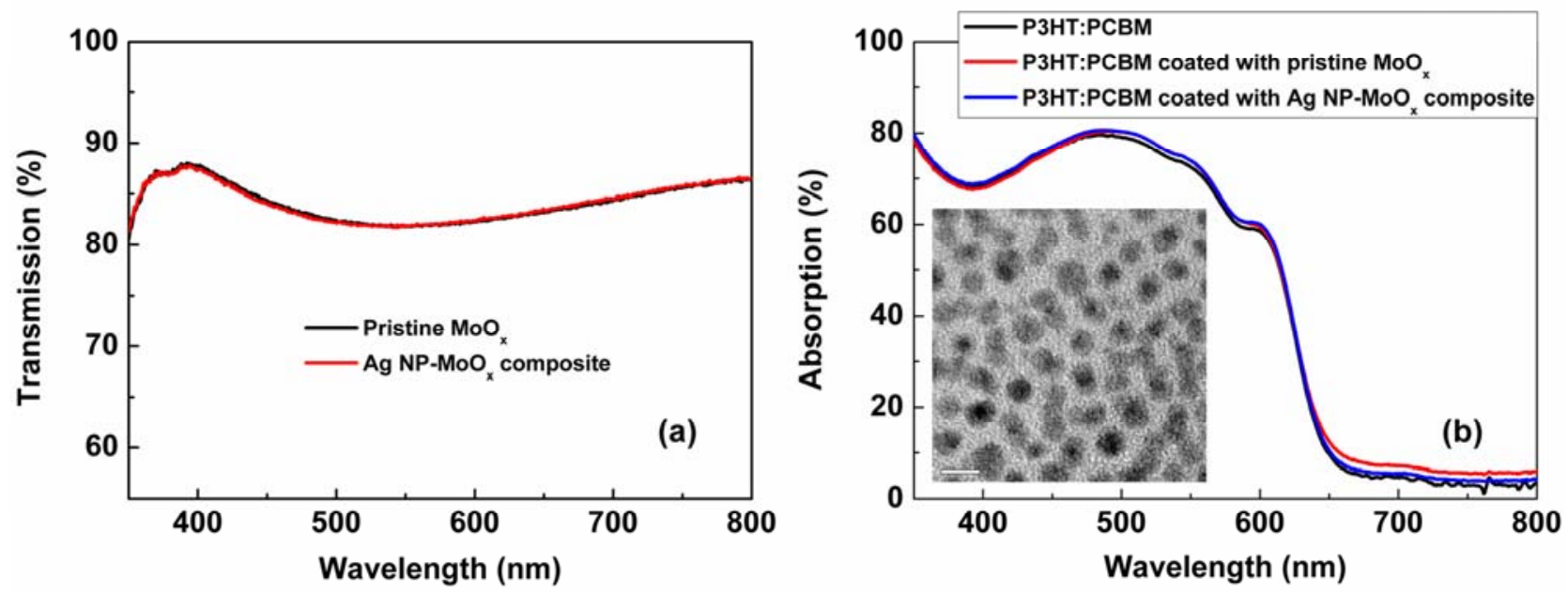

Fig. 6 (a) Transmission spectra of pristine $\mathrm{MoO}_{\mathrm{x}}$ film (black line) and Ag NP-MoO composite film (red line). (b) Absorption spectra of P3HT:PCBM film (black line), P3HT:PCBM coated with pristine $\mathrm{MoO}_{\mathrm{x}}$ film (red line), P3HT:PCBM coated with Ag NP-MoO composite film (blue line). (Inset: TEM 5 result of $4 \mathrm{~nm} \mathrm{Ag} \mathrm{NPs,} \mathrm{the} \mathrm{white} \mathrm{scale} \mathrm{bar} \mathrm{is} 5 \mathrm{~nm}$ in left bottom.)

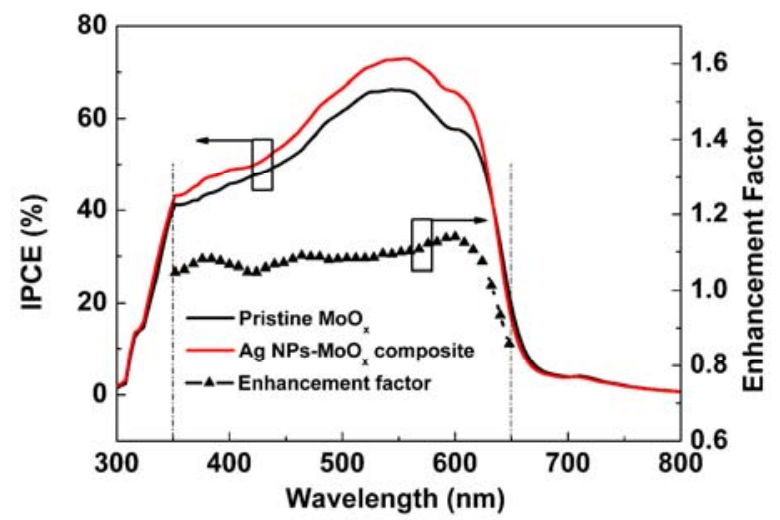

Fig. 7 IPCE spectra (left axis) of P3HT:PCBM OSCs with pristine $\mathrm{MoO}_{\mathrm{x}}$ and $\mathrm{Ag} \mathrm{NP}-\mathrm{MoO}_{\mathrm{x}}$ composite layer and the enhancement factor (right axis) in the core absorption region from $350 \mathrm{~nm}$ to $650 \mathrm{~nm}$, i.e., (IPCE of OSCs 10 with $\mathrm{Ag} \mathrm{NP}-\mathrm{MoO}_{\mathrm{x}}$ composite)/(IPCE of OSCs with pristine $\mathrm{MoO}_{\mathrm{x}}$ ).

Ag NP- $\mathrm{MoO}_{\mathrm{x}}$ composite film does not show obvious change in the transmission and absorption. We did not observe clear optical enhancement in the active layer of the inverted OSCs (i.e. no clear absorption enhancement due to plasmonic resonances).

${ }_{15}$ Consequently, optical enhancement is not likely a contributing factor to the improvement of device performance.

Interestingly, there is a wide wavelength band increment of IPCE as shown in Fig. 7, covering the core absorption region from $350 \mathrm{~nm}$ to $650 \mathrm{~nm}$ of P3HT:PCBM based OSCs. In addition, 20 no clear peak in the enhancement factor spectrum, i.e. (IPCE of

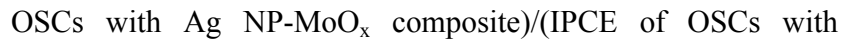
pristine $\mathrm{MoO}_{\mathrm{x}}$ ), can be observed in the core absorption region. The wideband enhancement suggests that the increase of $\mathrm{J}_{\mathrm{SC}}, \mathrm{FF}$ and PCE are contributed by the improved electrical properties ${ }^{44}$ ${ }_{25}$ due to the incorporation of $\mathrm{Ag} \mathrm{NPs}$ in the $\mathrm{Ag} \mathrm{NP}-\mathrm{MoO}_{\mathrm{x}}$ composite interfacial layer. Another IPCE spectra of OSCs using low band gap material as active layer and solution-processed $\mathrm{Ag}$
$\mathrm{NP}-\mathrm{MoO}_{\mathrm{x}}$ composite film also show wideband enhancement as shown in ESI Fig. S6.

30 To further verify this claim, we investigate hole dominated devices with the structure of ITO/PEDOT:PSS/P3HT:PCBM/ $\mathrm{MoO}_{\mathrm{x}} / \mathrm{Ag}$ with and without $\mathrm{Ag} \mathrm{NPs}$ in the $\mathrm{MoO}_{\mathrm{x}}$ film. ${ }^{45,}{ }^{46} \mathrm{As}$ shown in ESI Fig. S7, the current of the hole dominated device with $\mathrm{Ag} \mathrm{NP}-\mathrm{MoO}_{\mathrm{x}}$ composite film is much larger than the 35 pristine solution-processed $\mathrm{MoO}_{\mathrm{x}}$ and evaporated $\mathrm{MoO}_{3}$ film. This indicates the holes are more efficiently extracted to anode by using the $\mathrm{Ag} \mathrm{NP}-\mathrm{MoO}_{\mathrm{x}}$ composite as the hole transport layer. Another evidence can be obtained from transient photo-generated voltage (TPV) measurement. The TPV measured using the 40 excitation source of $532 \mathrm{~nm}$ picoseconds laser pulse shows that the transient voltage of the device with $\mathrm{Ag} \mathrm{NP}-\mathrm{MoO}_{\mathrm{x}}$ composite film decays faster than that of those devices without Ag NPs, which are shown in ESI Fig. S8. This indicates that the carrier will transfer faster through the $\mathrm{Ag} \mathrm{NP}-\mathrm{MoO}_{\mathrm{x}}$ composite film to 45 anode as compared to that of the pristine $\mathrm{MoO}_{\mathrm{x}}$ and evaporated $\mathrm{MoO}_{3}$ film. ${ }^{47}$ It should be noted that the hole dominated device and TPV measurement of the OSCs with the solution-processed $\mathrm{MoO}_{\mathrm{x}}$ film overlap with that of the evaporated $\mathrm{MoO}_{3}$ film. This re-confirms that the room-temperature solution-processed $\mathrm{MoO}_{\mathrm{x}}$ ${ }_{50}$ film functions as good as the evaporated $\mathrm{MoO}_{3}$ film as described before. Consequently, our results show that the room-temperature solution-process $\mathrm{Ag} \mathrm{NP}-\mathrm{MoO}_{\mathrm{x}}$ composite film can clearly work as efficient hole transport layer and improve the PCE of inverted OSCs. We also demonstrate that the improvement is mainly due 55 to the enhanced electrical properties of the hole transport layer by introducing Ag NPs to form the Ag NP-MoO ${ }_{x}$ composite film.

\section{Conclusion}

In conclusion, a new approach with the features of water-free, room-temperature and solution-based process $\mathrm{MoO}_{\mathrm{x}}$ film is ${ }_{60}$ proposed and demonstrated as efficient hole transport layer for inverted OSCs. Interestingly, the UPS and XPS results indicate that oxygen vacancies can be introduced in the molybdenum 
oxide thin film by vacuum treatment, which functionalize the $\mathrm{MoO}_{\mathrm{x}}$ film to be an efficient hole transport layer. Remarkably, further improvement of the electrical properties of the $\mathrm{MoO}_{\mathrm{x}}$ film is achieved by incorporating $\mathrm{Ag}$ NPs to form $\mathrm{Ag} \mathrm{NP}^{-\mathrm{MoO}_{x}}$ 5 composite film. Inverted OSCs with PCE of $7.94 \%$ are achieved by using the $\mathrm{Ag} \mathrm{NP}-\mathrm{MoO}_{\mathrm{x}}$ composite film as hole transport layer. Consequently, through the demonstration of high performance inverted OSCs with different polymer materials, the water-free, room-temperature and solution-processed $\mathrm{MoO}_{\mathrm{x}}$ film can

10 function as efficient hole transport layer for high performance organic optoelectronic devices, and with the further potential contribution to OLEDs and OSCs with inverted and tandem structured devices.

\section{Experimental Section}

\section{4.1 Molybdenum bronze solution synthesis and preparation}

Molybdenum powder was purchased from Aladdin. First $0.2 \mathrm{~g}$ metal powder was dispersed into $20 \mathrm{ml}$ ethanol with ultrasound bath. Then solution was mixed with $0.7 \mathrm{ml}$ hydrogen peroxide $(30 \%)$. Ethanol was used to control the reaction rate between 20 metal powders and hydrogen peroxide. During the reaction, ethanol will provide $\mathrm{e}^{-}$and $\mathrm{H}^{+}$for the reduction of the metal peroxide, meanwhile $\mathrm{H}^{+}$can be inserted into the metal oxide lattice to form metal oxide bronzes. ${ }^{27}$ After 20 hour reaction, molybdenum oxide solution turned from gray to blue attributed to

${ }_{25} \mathrm{H}^{+}$insertion into the metal oxide lattice and then the reduction of metal element $\left(\mathrm{Mo}^{6+}\right)$ into sub-state $\left(\mathrm{Mo}^{5+}\right)$, forming hydrogen molybdenum bronzes $\left(\mathrm{H}_{\mathrm{x}} \mathrm{MoO}_{3}\right)$. Finally, the remained solvent was exhausted in dry box, after which the obtained molybdenum bronze was dissolved into IPA with a concentration of $1 \mathrm{mg} \mathrm{ml}^{-1}$.

\section{4.2 Inverted OSCs device fabrication}

The device structure of inverted OSCs was $\mathrm{ITO} / \mathrm{TiO}_{2} /$ polymer blend active layer/ $/ \mathrm{MoO}_{\mathrm{x}} / \mathrm{Ag}$. The sheet resistance of the ITO was $15 \Omega \square^{-1}$. The glass substrate was cleaned with detergent, acetone and ethanol, and then treated under UV-ozone for $15 \mathrm{~min}$. The $35 \mathrm{TiO}_{2}$ film with a thickness of $\sim 20 \mathrm{~nm}$ was made by spin-coating $\mathrm{TiO}_{2}$ nanocrystals onto the ITO followed by $150^{\circ} \mathrm{C}$ baking for 10 min. $\mathrm{TiO}_{2}$ nanocrystals solution was prepared by the nonaqueous method in previously reported paper. ${ }^{48}$ In our inverted OSCs, the active layer was the robust polymer blend of P3HT:PCBM and

40 small band material of PBDTTT-C-T:PC ${ }_{71}$ BM. The P3HT:PCBM solution (20 mg ml${ }^{-1}: 20 \mathrm{mg} \mathrm{ml}^{-1}$, in 1,2-dichlorobenzen) was filtered and spin-coated. The sample was solvent annealed for 1 hour and annealed at $120^{\circ} \mathrm{C}$ for 10 minutes to form a film with a thickness of $\sim 220 \mathrm{~nm}$. For small band gap materials, PBDTTT-C${ }_{45} \mathrm{~T}: \mathrm{PC}_{71} \mathrm{BM}$ solution $\left(10 \mathrm{mg} \mathrm{ml}^{-1}: 18 \mathrm{mg} \mathrm{ml}^{-1}\right.$, in chlorobenzene, with $3 \%$ volume ratio 1,8 -diiodooctane (DIO)) was filtered and spin-coated to form a film with a thickness of $\sim 100 \mathrm{~nm}$. After spin-coating the active layer, it was put in the vacuum chamber of $\sim 10 \mathrm{~Pa}$ for 1 hour to remove the DIO. Our newly synthesized 50 molybdenum bronze solution was spin-coated onto the active layer with an optimized $3000 \mathrm{rpm}$. Then the sample was quickly put into $10 \mathrm{~Pa}$ vacuum chamber for $10 \mathrm{~min}$ treatment. The control device was fabricated by using thermally evaporated molybdenum oxide layer with an optimized thickness of $10 \mathrm{~nm}$.

${ }_{55}$ Silver anode of thickness $100 \mathrm{~nm}$ was finally evaporated onto the interfacial layer with a mask of $0.045 \mathrm{~cm}^{2}$ area. In fabricating the hole dominated devices with the structure ITO/PEDOT:PSS(30 $\mathrm{nm}) / \mathrm{P} 3 \mathrm{HT}: \mathrm{PCBM} / \mathrm{MoO}_{\mathrm{x}} / \mathrm{Ag}$, the same fabrication process of active layer as in the inverted structure OSCs has been used and 60 the active layers thickness $\sim 220 \mathrm{~nm}$ for all hole dominated devices.

\subsection{Synthesis of Ag NPs and Ag NP-MoO ${ }_{x}$ composite film}

To improve electrical properties of our solution processed $\mathrm{MoO}_{\mathrm{x}}$ film, Ag NPs were incorporated into molybdenum bronze ${ }_{65}$ solution. Ag NPs were synthesized by mixing $1 \mathrm{mmol} \mathrm{Ag}$ acetate, $3 \mathrm{mmol}$ oleylamine, $3 \mathrm{mmol}$ oleic acid, $20 \mathrm{ml}$ phenyl ether and steary alcohol. The mixture was magnetically stirred and dispersed under nitrogen ambience at $80{ }^{\circ} \mathrm{C}$. Heat the mixture in $195{ }^{\circ} \mathrm{C}$ for 1 hour. After cooling to room temperature, it was 70 added with $50 \mathrm{ml}$ ethanol and centrifuged to precipitate the $\mathrm{Ag}$ NPs. The precipitated Ag NPs can be well dispersed into nonpolar solvent hexane. Then the Ag NPs was further dispersed into IPA with a concentration of $0.5 \mathrm{mg} \mathrm{ml}^{-1}$. The Ag NPs synthesized by this method had an average diameter of $4 \mathrm{~nm}$, which can be 75 verified by the TEM result. To optimize the concentration of $\mathrm{Ag}$ NPs, molybdenum bronze solution was first concentrated to $2 \mathrm{mg}$ $\mathrm{ml}^{-1}$, after which, it was mixed with the same volume of different diluted concentration of Ag NPs solution.

\subsection{Measurement and characterization}

${ }_{80}$ UPS measurement was taken by He I discharge lamp (Kratos Analytical) with energy of $21.22 \mathrm{eV}$ and a resolution of $0.15 \mathrm{eV}$. A $-10 \mathrm{~V}$ bias was added on samples to enhance the measured signals. XPS measurement was performed using Physical Electronic 5600 multi-technique system (monochromatic Al Ka ${ }_{85} \mathrm{X}$-ray source). The J-V characteristics were measured using ABET AM $1.5 \mathrm{G}$ solar simulator with a light intensity of 100 $\mathrm{mW} \mathrm{cm}{ }^{-2}$ and a Keithley 2635 source meter. TEM was measured by FEI Tecnai G2 20 S-TWIN Scanning Transmission Electron Microscope. The thickness of film was measured by ellipsometer. 90 The SEM was measured by LEO 1530 FEG Scanning Electron Microscope.

\section{Acknowledgements}

This work is supported by University Grant Council of the University of Hong Kong (grants \#10401466 and 95 \#201111159062), the General Research Fund (grants: HKU\#712010E and HKU711612E) and the RGC-NSFC grant (N_HKU709/12) from the Research Grants Council of Hong Kong Special Administrative Region, China. J. Hou would like to acknowledge the financial support from National high technology 100 research and development program 863 (2011AA050523) and NSFC (No.51173189).

\section{Notes and references}

${ }^{a}$ Department of Electrical and Electronic Engineering, The University of Hong Kong, Pokfulam Road, Hong Kong, China.

$105{ }^{b}$ Institute of Chemistry, Chinese Academy of Sciences, Beijing 100190, China.

*Corresponding author: chchoy@eee.hku.hk (Choy)

$\dagger$ Electronic Supplementary Information (ESI) available: [Additional information details about optimized thickness of solution-processed $110 \mathrm{MoO}_{\mathrm{x}}$ interfacial layer, optical band gap, IPCE of compared OSCs using P3HT:PCBM polymer blends with different interfacial layers, $\mathrm{J}_{\text {dark }}-\mathrm{V}$ 
characteristics of OSCs with $\mathrm{Ag}$ NP- $\mathrm{MoO}_{\mathrm{x}}$ composites, IPCE of compared OSCs using small band gap material polymer blends with different interfacial layers, J-V characteristics of hole dominated devices with different interfacial layers, TPV measurement of OSCs with different 5 interfacial layers, and SEM images of pristine $\mathrm{MoO}_{\mathrm{x}}$ film and Ag NP$\mathrm{MoO}_{\mathrm{x}}$ composite film]. See DOI: 10.1039/b000000x/

1. M. T. Greiner, M. G. Helander, W. M. Tang, Z. B. Wang, J. Qiu and Z. H. Lu, Nat. Mater., 2011, 11, 76-81.

2. J. Y. Kim, S. H. Kim, H. H. Lee, K. Lee, W. Ma, X. Gong and A. J.

$10 \quad$ Heeger, Adv. Mater., 2006, 18, 572-576.

3. Z. a. Tan, L. Li, C. Cui, Y. Ding, Q. Xu, S. Li, D. Qian and Y. Li, J. Phys. Chem. C, 2012, 116, 18626-18632.

4. J. Meyer, K. Zilberberg, T. Riedl and A. Kahn, J. Appl. Phys., 2011, 110, 033710-033710-033715.

15 5. T. Yang, W. Cai, D. Qin, E. Wang, L. Lan, X. Gong, J. Peng and Y. Cao, J. Phys. Chem. C, 2010, 114, 6849-6853.

6. M. D. Irwin, D. B. Buchholz, A. W. Hains, R. P. H. Chang and T. J. Marks, Proc. Natl. Acad. Sci. U. S. A., 2008, 105, 2783-2787.

7. A. Kyaw, X. Sun, C. Jiang, G. Lo, D. Zhao and D. Kwong, Appl. Phys.

20 Lett., 2008, 93, 221107-221107-221103.

8. G. Li, R. Zhu and Y. Yang, Nat. Photonics, 2012, 6, 153-161.

9. M. De Jong, L. Van Ijzendoorn and M. De Voigt, Appl. Phys. Lett., 2000, 77, 2255.

10. Y. Sun, C. J. Takacs, S. R. Cowan, J. H. Seo, X. Gong, A. Roy and A.

25 J. Heeger, Adv. Mater., 2011, 23, 2226-2230.

11. S. Murase and Y. Yang, Adv. Mater., 2012, 24, 2459-2462.

12. Y. Nakayama, K. Morii, Y. Suzuki, H. Machida, S. Kera, N. Ueno, H. Kitagawa, Y. Noguchi and H. Ishii, Adv. Funct. Mater., 2009, 19, 3746-3752.

30 13. J. Meyer, R. Khalandovsky, P. Görrn and A. Kahn, Adv. Mater., 2011, 23, 70-73.

14. F. Liu, S. Shao, X. Guo, Y. Zhao and Z. Xie, Sol. Energy Mater. Sol. Cells, 2010, 94, 842-845.

15. J. J. Jasieniak, J. Seifter, J. Jo, T. Mates and A. J. Heeger, Adv. Funct. Mater., 2012, 22, 2594-2605.

16. T. Yang, M. Wang, Y. Cao, F. Huang, L. Huang, J. Peng, X. Gong, S. Z. D. Cheng and Y. Cao, Adv. Energy Mater., 2012, 2, 523-527.

17. T. Stubhan, T. Ameri, M. Salinas, J. Krantz, F. Machui, M. Halik and C. J. Brabec, Appl. Phys. Lett., 2011, 98, 253308.

40 18. A. Göpferich, Biomaterials, 1996, 17, 103-114.

19. M. Jørgensen, K. Norrman and F. C. Krebs, Sol. Energy Mater. Sol. Cells, 2008, 92, 686-714.

20. B. Ecker, J. C. Nolasco, J. Pallarés, L. F. Marsal, J. Posdorfer, J. Parisi and E. von Hauff, Adv. Funct. Mater., 2011, 21, 2705-2711.

45 21. J. S. Huang, C. Y. Chou, M. Y. Liu, K. H. Tsai, W. H. Lin and C. F. Lin, Org. Electron., 2009, 10, 1060-1065.

22. C. Girotto, E. Voroshazi, D. Cheyns, P. Heremans and B. P. Rand, ACS Appl. Mater. Interfaces, 2011, 3, 3244-3247.

23. S. L. Madorsky, Thermal degradation of organic polymers, RE

50 Krieger Publishing Company, 1975.

24. C. H. Bamford and C. F. H. Tipper, Degradation of polymers, Elsevier Science Limited, 1975.

25. K. Kawano and C. Adachi, Adv. Funct. Mater., 2009, 19, 3934-3940. 26. Y.-J. Lee, J. Yi, G. F. Gao, H. Koerner, K. Park, J. Wang, K. Luo, R.

55 A. Vaia and J. W. P. Hsu, Adv. Energy Mater., 2012, 2, 1193-1197.

27. S. Ayyappan and C. Rao, Mater. Res. Bull., 1995, 30, 947-951.
28. Y. Sun, J. H. Seo, C. J. Takacs, J. Seifter and A. J. Heeger, Adv. Mater., 2011, 23, 1679-1683.

29. J. You, C.-C. Chen, L. Dou, S. Murase, H.-S. Duan, S. A. Hawks, T.

60 Xu, H. J. Son, L. Yu, G. Li and Y. Yang, Adv. Mater., 2012, 24, 52675272.

30. A. Abdellaoui, G. Leveque, A. Donnadieu, A. Bath and B. Bouchikhi, Thin Solid Films, 1997, 304, 39-44.

31. R. J. Colton, A. M. Guzman and J. W. Rabalais, J. Appl. Phys., 1978, $65 \quad 49,409-416$.

32. M. A. B. de Moraes, B. C. Trasferetti, F. P. Rouxinol, R. Landers, S. F. Durrant, J. Scarmínio and A. Urbano, Chem. Mater., 2004, 16, 513520 .

33. M. Greiner, M. Helander, Z. Wang, W. Tang, J. Qiu and Z. Lu, Appl. Phys. Lett., 2010, 96, 213302.

34.G. Mestl, C. Linsmeier, R. Gottschall, M. Dieterle, D. Herein, J. Jäger, Y. Uchida and R. Schlögl, J. Mol. Catal. A: Chem., 2000, 162, 463492.

35. C. I. Wu, C. T. Lin, G. R. Lee, T. Y. Cho, C. C. Wu and T. W. Pi, J. 75 Appl. Phys., 2009, 105, 033717-033717-033714.

36. S. Deb and J. Chopoorian, J. Appl. Phys., 1966, 37, 4818-4825.

37. T. S. Sian and G. Reddy, Sol. Energy Mater. Sol. Cells, 2004, 82, 375386 .

38. L. Huo, S. Zhang, X. Guo, F. Xu, Y. Li and J. Hou, Angew. Chem., $80 \quad 2011,123,9871-9876$.

39. X. Li, W. C. H. Choy, L. Huo, F. Xie, W. E. I. Sha, B. Ding, X. Guo, Y. Li, J. Hou, J. You and Y. Yang, Adv. Mater., 2012, 24, 3046-3052.

40. D. H. Wang, D. Y. Kim, K. W. Choi, J. H. Seo, S. H. Im, J. H. Park, O. O. Park and A. J. Heeger, Angew. Chem. Int. Ed., 2011, 50, 5519$85 \quad 5523$.

41. F.-X. Xie, W. C. H. Choy, C. C. D. Wang, W. E. I. Sha and D. D. S. Fung, Appl. Phys. Lett., 2011, 99, 153304.

42. C. C. D. Wang, W. C. H. Choy, C. Duan, D. D. S. Fung, W. E. I. Sha, F.-X. Xie, F. Huang and Y. Cao, J. Mater. Chem., 2012, 22, 1206$90 \quad 1211$.

43. A. P. Kulkarni, K. M. Noone, K. Munechika, S. R. Guyer and D. S. Ginger, Nano Lett., 2010, 10, 1501-1505.

44. D. D. S. Fung, L. Qiao, W. C. H. Choy, C. Wang, W. E. I. Sha, F. Xie and S. He, J. Mater. Chem., 2011, 21, 16349-16356.

95 45. V. D. Mihailetchi, J. K. J. van Duren, P. W. M. Blom, J. C. Hummelen, R. A. J. Janssen, J. M. Kroon, M. T. Rispens, W. J. H. Verhees and M. M. Wienk, Adv. Funct. Mater., 2003, 13, 43-46.

46. C. Melzer, E. J. Koop, V. D. Mihailetchi and P. W. M. Blom, Adv. Funct. Mater., 2004, 14, 865-870.

100 47. B.-F. Ding, W. C. H. Choy, W.-M. Kwok, C.-D. Wang, K. Y. F. Ho, D. D. S. Fung and F.-X. Xie, Phys. Chem. Chem. Phys., 2012, 14, 8397-8402.

48. G. V. Jensen, M. Bremholm, N. Lock, G. R. Deen, T. R. Jensen, B. B. Iversen, M. Niederberger, J. S. Pedersen and H. Birkedal, Chem. 105 Mater., 2010, 22, 6044-6055. 